\title{
Agricultural concepts of roots: from morphogenetic to functional equilibrium between root and shoot growth ${ }^{1}$
}

\author{
M. van Noordwijk and P. de Willigen
}

Institute for Soil Fertility, P.O. Box 30003, NL 9750 RA Haren, Netherlands

Received 9 July 1986; accepted 22 May 1987

Key words: water-table, deep soil tillage

\begin{abstract}
Concepts of the importance of root growth and function for plant production have changed gradually over the past century from a 'morphogenetic equilibrium' between root and shoot growth, which can be summarized as 'the more roots the better shoot growth', to a 'functional equilibrium' which puts emphasis on the water and nutrient uptake by the root system and not on the size of the root system as such. In fact, separate optima for root growth and shoot growth (dependent on root function) can often be distinguished. To obtain maximum crop production, relatively small root systems can be sufficient, provided the supply of water and nutrients is continuously high. Agricultural interventions aimed at increasing rooting depth by lowering the water-table or by deep soil tillage may be counterproductive for plant growth. Larger root systems may, however, reduce risks under rapidly changing environmental conditions and may increase nutrient use efficiency and hence reduce nutrient losses to the environment. Concepts are discussed in a historical perspective and examples are given of the empirical evidence to support or refute them.
\end{abstract}

\section{Introduction}

Roots link plant and soil. Concepts of root growth and function therefore are important for understanding effects of soil conditions on plant growth. Concepts of the role of roots in plant growth have varied over the past century from the plantcentred view of a 'morphogenetic equilibrium' between root and shoot growth to the soil-centred view of an 'environmental determinism' by which soil factors govern root growth. In the past decades a synthesis of these two views was formulated in the hypothesis of a 'functional equilibrium' between shoot and root growth (Brouwer, 1963, 1983). In this article the various concepts will be formulated and

\footnotetext{
${ }^{1}$ Dedicated to the memory of Prof. Dr R. Brouwer.
} 
discussed in view of the response of both root and shoot growth to variations in nutrient and water supply in the soil as a result of agricultural interventions. Several of the older concepts continue to be passed on to younger generations in textbooks as part of our agricultural heritage or folklore, despite their falsification in various field experiments.

\section{Morphogenetic equilibrium}

In the older literature (Schulze, 1911) many attempts were made to directly relate rooting depth to plant height, or lateral root expansion to crown diameter of trees. Shoot:root ratios expressed on this basis appeared to be very variable. Still, shortstraw cultivars of cereals were suspected to be shallow-rooted (Lupton et al., 1974). When the idea of a direct correspondence of root and shoot length (a 'morphological equilibrium) was refuted the concept of a 'morphogenetic equilibrium' remained.

In the concept of a morphogenetic equilibrium the complete attainment of the potential above-ground production depends on the full realization of the belowground growth potential. This was expressed by Hellriegel in 1883 in a 'basic law of agriculture': 'Das gesamte Wachstum der oberirdischen Pflanze ist streng abhängig von dem Entwicklungsgrade, den die Wurzel erreicht. Nur wenn die letztere sich zu ihrer höchsten Vollkommenheit auszubilden vermag, kann sich die oberirdische Pflanze in aller Üppigkeit entfalten' (Schulze, 1911). The main task for root research in this context was to separate the 'ideal type' of root system of each crop or plant species from the environmental modification of this type found in a given situation. This proved to be no simple task, as the adaptability of root growth is pronounced. Quantitative measurements of root and shoot growth, however, raised doubt about the validity of Hellriegel's law. Tucker \& von Seelhorst (1898) performed pot experiments in which root and shoot growth were recorded under different soil moisture contents and fertilizer levels (Fig. 1). The results clearly show that maximum shoot growth occurred in the wettest pots, while maximum root production was found in drier soil. The consequences of this falsification of Hellriegel's law were not fully accepted, however. For a long time the increase in root growth which can be observed when water-tables are lowered was considered to be an inherently positive effect of drier soil, even when susceptibility to drought was increased by such measures. Agricultural interventions such as lowering the watertable or deep soil tillage often result in better growth of both roots and shoots in the first year(s) after the intervention. On further analysis, this effect is not due to Hellriegel's law but to a temporarily increased mineralization of soil organic matter, supplying extra nitrogen to the crop (see below).

More recently, versions of the 'morphogenetic equilibrium' concept are stated in the form of a 'hormonal equilibrium': hormones produced in the root are essential for shoot growth and vice versa. According to this concept a continuous activity of inormone-producing root meristems is required for shoot growth and this hormone production function of roots, rather than their nutrient and water uptake, may limit plant growth. This view leads to the expectation that plant growth can be promoted 


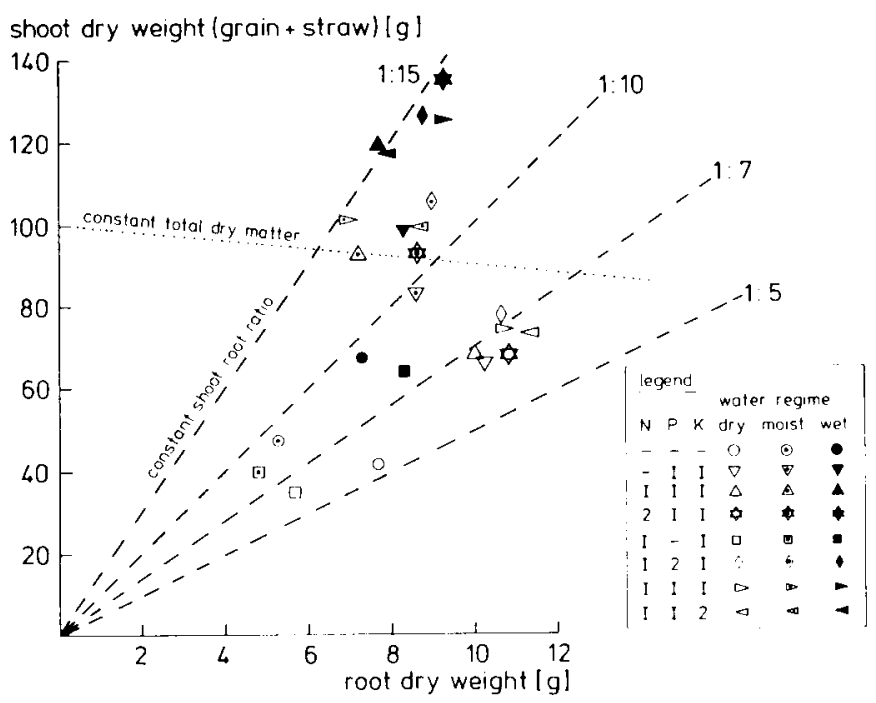

Fig. 1. Root and shoot dry weight of oats in pots maintained at three different soil moisture contents by frequent weighing and watering, with various fertilization levels (Tucker \& von Seelhorst, 1898).

by supplying extra hormones (or related substances) to the plants, in the form of organic manures (bacterial) preparations or synthetic hormones. Although it is possible to overrule the internal regulation of root and shoot growth with such substances, the modified plants are seldom better adapted in using environmental resources; externally applied hormones often act as herbicides.

\section{Environmental determinism}

As manipulating the root's environment often has considerable effects on root growth, it is understandable that a form of 'environmental determinism' developed. 'Phosphate stimulates root development' and 'water attracts roots' (hydrotropism) are typical statements of this view. These statements were based mainly on observations that $\mathbf{P}$-deficient plants develop extra branch roots near local phosphate supplies and that roots of water-stressed plants develop primarily in moist zones of the soil. Although experiments such as those of Goedewaagen (1932) showed that the local root response disappeared in plants well supplied with $\mathrm{P}$, the misinterpretation that $\mathrm{P}$ will always stimulate root development led to recommendations to fertilize the subsoil with $\mathbf{P}$ in the presence of P-rich topsoil, to stimulate deep root development (see below). De Jager (1985) has shown that the local response is not specific for $\mathrm{P}$, but can be observed for any nutrient (at least $\mathrm{N}, \mathrm{P}, \mathrm{K}$ and $\mathrm{S}$ ) in short supply in the plant as a whole. The nutrient status of the plant, in combination with the degree of heterogeneity of the external nutrient supply, determines whether or not a local root response will occur. 


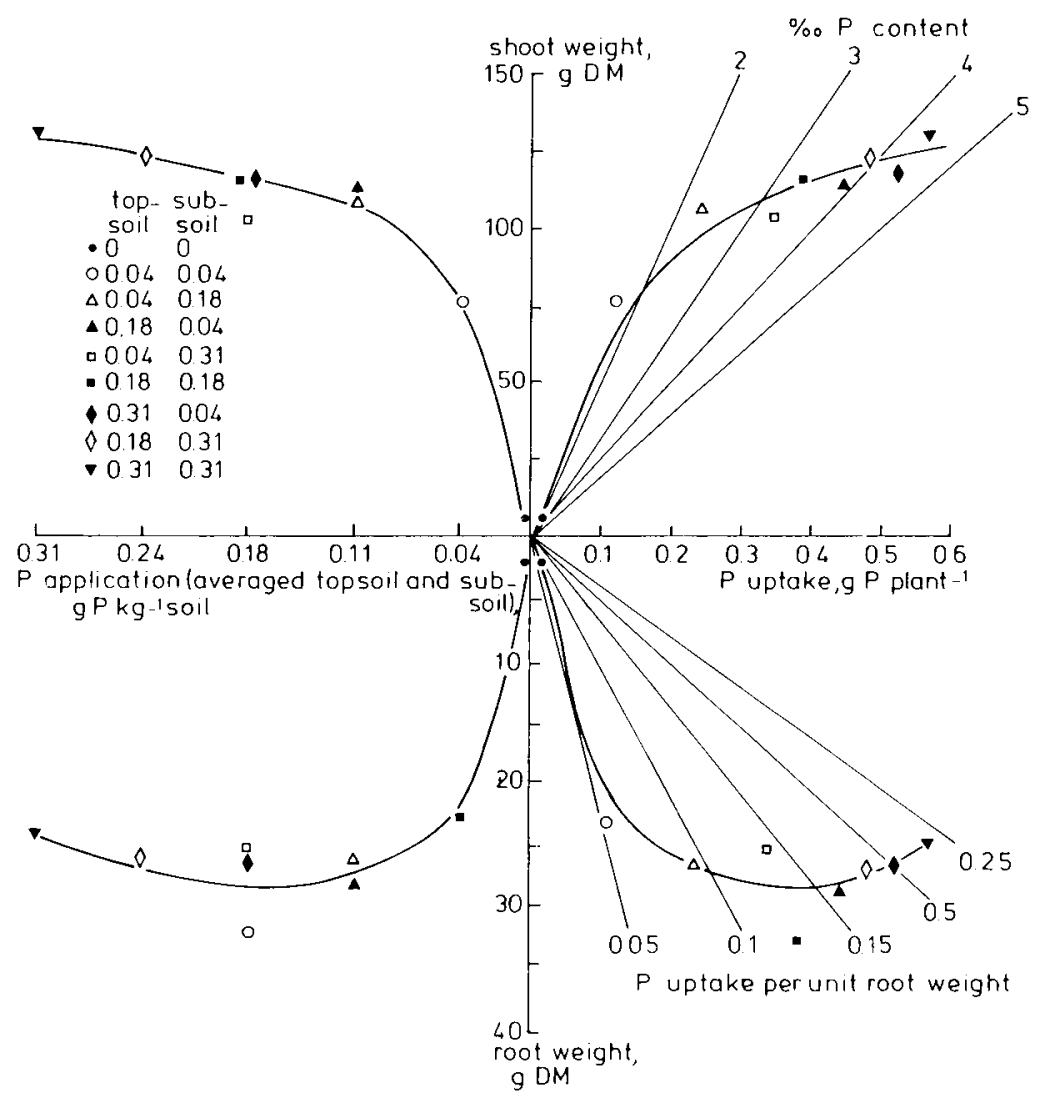

Fig. 2. Response of root and shoot growth of wheat to variation in P supply in top- and subsoil (Goedewaagen, 1937).

When the effects of variation in nutrient levels or water availability on root and shoot were investigated, a double-optimum curve usually was the result. Phosphate is no exception, as shown in Fig. 2 (Goedewaagen, 1937). Generally the optimum for root growth occurs at a lower external supply than the optimum for shoot growth and root function (nutrient and water uptake). This effect was discussed by Goedewaagen (1937) for $\mathrm{N}$ and $\mathrm{P}$ and later presented in graphical form by Schuurman (1983) (Fig. 3). Although this observation in fact falsified the previous expectation that more roots will always give better crop growth, the negative effects on root growth at a high external nutrient level were usually seen as something inherently bad. The idea that this response reflected a meaningful response of the plant to external conditions only gradually gained ground.

An interesting form of environmental determinism can be found in plant physiological studies of nutrient uptake. For a long time researchers in this field con- 


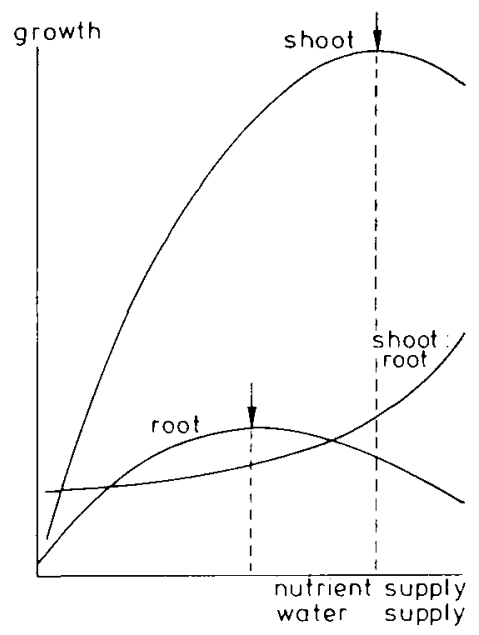

Fig. 3. Schematic response of root and shoot growth of annual plants to variation in the supply of water and nutrients (Schuurman, 1983).

sidered nutrient uptake rates to be governed by external concentrations and failed to accept the plant as a regulatory system, basically in control of its relationship with the environment by adjusting its uptake rate to current internal demand (Clarkson, 1985). The dominant school in modelling solute uptake by plants from soil (Nye \& Tinker, 1977; Barber, 1984) followed this physiological description, giving priority to the concentration at the root surface as the factor governing uptake rates.

\section{Functional equilibrium}

Boonstra (1934) defined 'root value' as plant dry matter production per unit root weight and used this quantity for selecting cultivars with small but efficient root systems. This approach was an early attempt to quantify root functions for the whole plant. Cultivars with a high shoot:root ratio under fertile conditions gave a greater (shoot) yield than cultivars with a low shoot:root ratio and absorbed more water and minerals per unit root dry weight (Goedewaagen, 1937). Goedewaagen distinguished between two explanations for increased uptake of nutrients from the soil, which may be termed the 'morphological response' (extra root growth) and the 'functional response' (extra uptake activity per unit root) to the environment.

Such considerations from the plant's point of view and the demonstration of active regulation by the plant to restore root:shoot balance after disturbance by removing part of either organ led to the concept of a 'functional equilibrium' between shoot and root growth, in response to environmental conditions (Brouwer, 1963; 1983). The essential difference from the 'morphogenetic equilibrium' is that in this concept the shoot and root are not assumed to respond to the size of the other plant 
part, but to the effectiveness with which basic needs are obtained by the complementary organs from the environment. The main difference from the 'environmental determinism' is that the response to external factors depends on the internal situation (energy, nutrients, water potential, hormones) in the plant. In Brouwer's concept the proximate level of regulation, by competition between root and shoot for carbohydrates and nutrients, is directly coupled to the environmental factors which determine the ultimate sense or non-sense of the plant's growth response. Further studies have shown that internal control of the proximate level can be exerted in various ways (Lambers, 1983). The functional equilibrium concept together with considerations of nutrient and water supply in the soil may explain two types of empirical evidence, not accounted for by the previous concepts: small root systems may be sufficient for maximum plant growth when the supply of water and nutrients is optimal and manipulating the soil to obtain more roots may be counterproductive.

\section{Small root systems may be sufficient for maximum plant growth}

The experiment of Tucker \& von Seelhorst (1898) shown in Fig. 1 demonstrated that a comparatively small root system in continuously moist and nutrient-rich soil in the pots allowed a maximum shoot production. The presence of many roots does
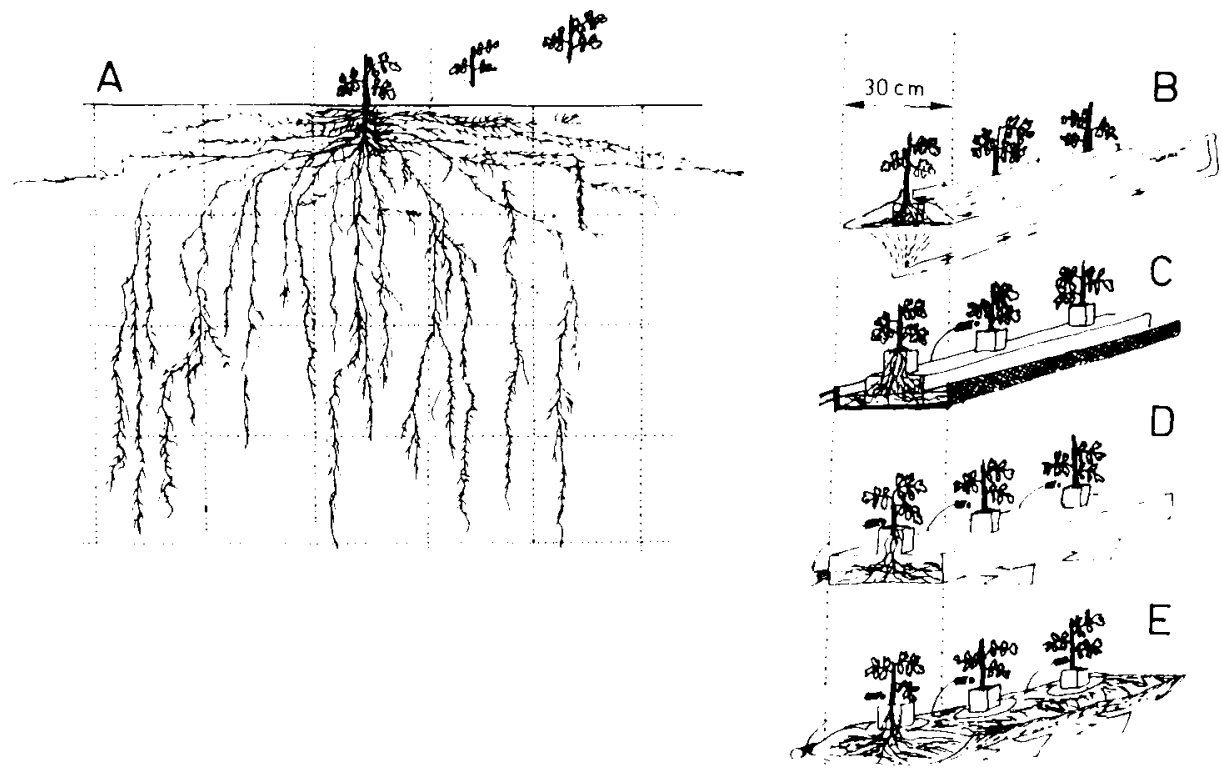

Fig. 4. Comparison of the root system of a soil-grown tomato plant with the volume available to roots in modern horticulture using artificial substrates. 
not necessarily coincide with a high uptake rate of water and nutrients, and a weakly branched root system may sometimes achieve much more than one would expect. Other situations where small root systems are able to support (near-)maximum crop growth occurred:

- in recently reclaimed polders under constantly wet and fertile conditions (Goedewaagen, 1955),

- under supplementary fertilization in compacted soils (Schuurman, 1971), and

- in nutrient solutions in artificial substrates in horticulture (Fig. 4; van Noordwijk \& Raats, 1980), root:shoot ratios on a dry weight basis may be $1: 20$, while the total root surface area is still half as large as the leaf surface area per plant.

\section{Manipulating the soil for more roots may be counterproductive}

High water-tables in the growing season restrict root development. Lowering the water-table usually results in an increase of rooting depth. Positive effects on crop yield of lowering the water-table in field experiments could, however, be mainly attributed to a temporary increase in mineralization of soil organic matter, providing $\mathrm{N}$ to the crop (van Hoorn 1958), not to the increased root development as such. In mechanized agriculture soil compaction can be reduced by maintaining drier soil. Thus, lowering the groundwater level may be economically favourable for the farmer, even when effects on plant growth as such are negative. Fig. 5 shows results obtained by Schuurman et al. (1977) in a long-term soil column experiment with variation in the water-table, without soil compaction by machinery. Negative effects of low water-tables on crop yield in dry years are larger than positive effects in wet years. A direct consequence of the lowering of groundwater levels in agricultu-
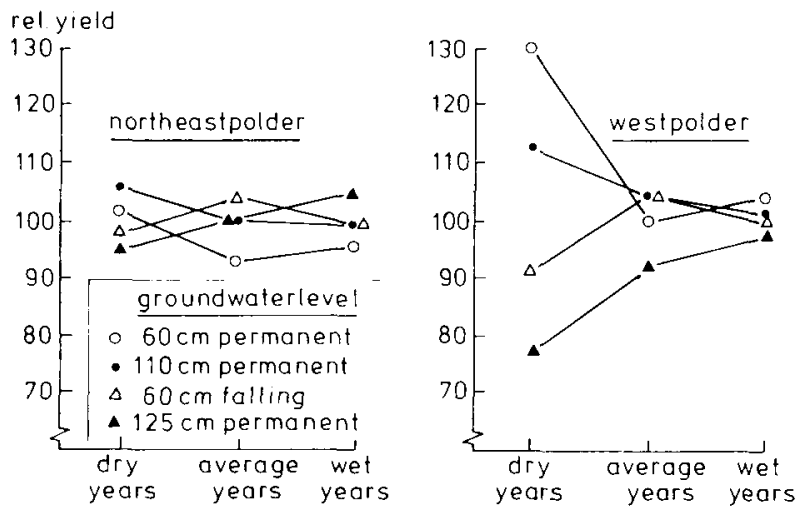

Fig. 5. Effect of groundwater levels on $9 \mathrm{loam} / \mathrm{sand}$ profiles in large columns with undisturbed soil profiles ( 4 from Noordoostpolder, 5 from Westpolder, N. Groningen). Relative yields are shown as the aggregate over a crop rotation for four groundwater levels (constant at depths of 60,110 and more than 125 $\mathrm{cm}$, or starting at $60 \mathrm{~cm}$ and falling during growing season). Years were classified according to water deficit in the growing season (Schuurman et al., 1977). 
ral land improvement schemes in the Netherlands is an increased need for (sprinkler) irrigation in dry periods. The main effect of sprinkler irrigation may be to restore a sufficient moisture content in the topsoil to allow diffusion of nutrients to the roots (Garwood \& Williams, 1967). The separation of a wet root environment from
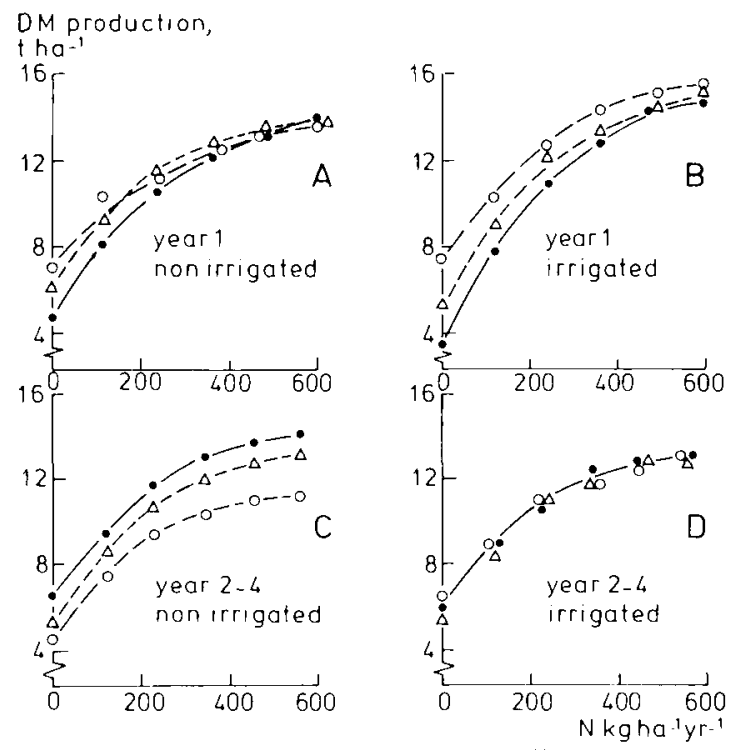

no of vertical roots per $\mathrm{cm}^{2}$
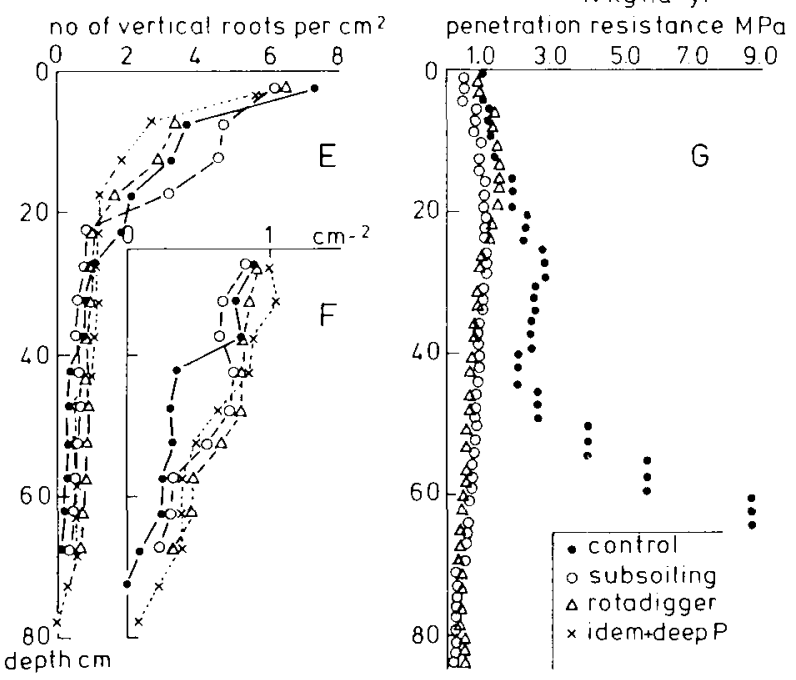

Fig. 6. Effects of deep soil tillage on grassland on a sandy soil at Heino. A-D: grass yields in the first experimental year (1977) and in subsequent years (average for 1978-1980) in relation to $\mathrm{N}$ fertilization and sprinkler irrigation. E, F: root development. G: penetration resistance (A-D and G based on Schothorst \& Hettinga, 1983). 
a solid support for agricultural traffic, which is characteristic of modern glasshouse horticulture (Fig. 4), has not been introduced in agriculture as yet.

Deep soil tillage in situations where an impenetrable layer prevents deep root development may have positive effects on drought resistance of crops if it makes a deep water-table accessible to the root system. In other cases manipulation of the soil to increase root penetration has given no or negative effects on crop yields apart from first year's $\mathrm{N}$ effects. Fig. 6 shows results for a deep soil tillage experiment on grassland (Schothorst \& Hettinga, 1983). Deep soil tillage effectively reduced the penetration resistance of the soil and had the expected positive effects on root development. Deep P-fertilization had no effect on root development in the presence of P-rich topsoil. Positive effects of deep tillage operations on grass yield in the first year, however, existed only at low levels of nitrogen. In the subsequent years this nitrogen effect of soil tillage disappeared and the grass appeared to be more rather than less sensitive to drought as a result of the intervention. Measurements showed that moisture storage in the (sandy) soil was reduced by loosening the soil (Schothorst \& Hettinga, 1983).

As the hydraulic properties of soils may be improved by soil compaction while root development may be hindered, the overall effect of moderate soil compaction as found under zero-tillage cannot easily be predicted.

\section{Discussion}

To obtain maximum above-ground production, large root systems apparently are not required if water and nutrients are continuously available. When this condition is not met, however, larger root systems may reduce the consequence of sudden variations in nutrient and water supply. Where a substantial risk of drought stress exists, selection of cultivars with large root systems (the reverse of Boonstra's choice) may be beneficial. In selecting cultivars it is possible to shift the relative position of the optima for root and shoot growth shown in Fig. 3. By a more complete depletion of potentially available nutrient supplies in the soil larger root systems may also improve the nutrient use efficiency of a crop and reduce nutrient losses to the environment. These general relations require further quantification.

The concept of the 'functional equilibrium' suggests that the most meaningful way to express shoot:root ratios may be on the basis of the size of their interface with the environment, i.e. the ratio of leaf area to root area. Considerable progress has been made in relating 'photosynthetic efficiency' to shoot architecture and leaf area index (LAI, total leaf surface area per unit cropped area) (de Wit \& Penning de Vries, 1983). Parallel efforts to relate 'nutrient and water use efficiency' to root architecture and root area index (RAI, total root surface area per unit cropped area) are more fragmentary as yet. As outlined elsewhere (van Noordwijk \& de Willigen, 1986) we try to develop such a theory, starting from the assumption that a plant fully controls the uptake rates of water and nutrients according to its demands as long as the supply to the root is sufficient. 


\section{VAN NOORDWIJK AND P. DE WILLIGEN}

\section{References}

Barber, S. A., 1984. Soil nutrient bioavailability: a mechanistic approach. John Wiley, New York, 398 pp.

Boonstra, A. E. H. R., 1934. Physiological research serving plant breeding (in Dutch). Doctoral thesis, University of Utrecht.

Brouwer, R., 1963. Some aspects of the equilibrium between overground and underground plant parts. Jaarboek IBS Wageningen 1963: 31-39.

Brouwer, R., 1983. Functional equilibrium: sense or nonsense? Netherlands Journal of Agricultural Science 31: 335-348.

Clarkson, D. T., 1985. Factors affecting mineral nutrient acquisition by plants. Annual Review of Plant Physiology 36: 77-115.

Garwood, E. A. \& T. E. Williams, 1967. Growth, water use and nutrient uptake from the subsoil by grass swards. Journal of Agricultural Science 69: 125-130.

Goedewaagen, M. A. J., 1932. Growth of the root system of plants at equal and different fertility of topsoil and subsoil (in Dutch). Verslagen Landbouwkundige Onderzoekingen 38A: 179-199.

Goedewaagen, M. A. J., 1937. The relative weight of shoot and root of different crops and its agricultural significance in relation to the amounts of phosphate added to the soil. Soil Science 44: 185-202.

Goedewaagen, M. A. J., 1955. The ecology of the root system of crops (in Dutch). In: The plant root in agriculture (in Dutch), p. 31-68. Staatsuitgeverij, Den Haag.

Hoorn, J. W. van, 1958. Results of a groundwater level exprimental field with arable crops on clay soil. Netherlands Journal of Agricultural Science 6: 1-10.

Jager, A. de, 1985. Response of plants to a localized nutrient supply. Doctoral thesis, University of Utrecht.

Lambers, H., 1983. 'The functional equilibrium', nibbling on the edges of a paradigm. Netherlands Journal of Agricultural Science 31: 305-311.

Lupton, F. G. H., R. H. Oliver, F. B. Ellis, B. T. Barnes, K. R. Howse, P. J. Welbank \& P. J. Taylor, 1974. Root and shoot growth of semidwarf and taller winterwheats. Annals of Applied Biology 77: $129-144$

Noordwijk, M. van \& P. A. C. Raats, 1980. Drip and drainage systems for rockwool cultures in relation to accumulation and leaching of salts. Proceedings 5th International Congress on Soilless Culture (Wageningen), p. 279-287.

Noordwijk, M. van \& P. de Willigen, 1986. Quantitative root ecology as element of soil fertility theory. Netherlands Journal of Agricultural Science 34: 273-281.

Nye, P.H. \& P. B. Tinker, 1977. Solute movement in the soil-root system. Studies in Ecology, Volume 4. Blackwell Scientific Publications, Oxford, 342 pp.

Schothorst, C. J. \& D. Hettinga, 1983. Soil improvement: an alternative for artificial raining on grassland on light-textured sandy soils? (in Dutch). Bedrijfsontwikkeling 14: 115-122.

Schulze, B., 1911. Wurzelatlas; Darstellung natürlicher Wurzelbilder der Halmfrüchte in verschiedenen Stadien der Entwicklung. Paul Parey, Berlin.

Schuurman, J. J., 1971. Effect of supplemental fertilization of oats with restricted root development. Zeitschrift für Acker- und Pflanzenbau 133: 315-320.

Schuurman, J. J., 1983. Effect of soil conditions on morphology and physiology of roots and shoots of annual plants. A generalized vision. In: Wurzelökologie und ihre Nutzanwendung, p. 343-354. Bundesanstalt Gumpenstein, Irdning, Austria.

Schuurman, J. J., J. T. N. Venekamp and R. J. de Glopper, 1977. The production potential of different loam-on-sand profiles at four groundwater tables (in Dutch). Cultuurtechnisch Tijdschrift 17: 17-31.

Tucker, M. \& C. von Seelhorst, 1898. Der Einfluss welchen der Wassergehalt und der Reichtum des Bodens auf die Ausbildung der Wurzeln und der oberirdischen Organe der Haferpflanzen ausüben. Journal für Landwirtschaft 46: 52-63.

Wit, C. T. de \& F. W. T. Penning de Vries, 1983. Crop growth models without hormones. Netherlands Journal of Agricultural Science 31: 313-323. 